\title{
Maximum Carbon Intensity Limitations and the Agreement on Technical Barriers to Trade
}

Charles Owen Verrill, Jr.*

Emission of greenhouse gases is a global problem. Any nation seeking to restrict such emissions by its manufacturers should avoid putting them at a disadvantage in world and domestic markets where they are likely to compete with producers that do not bear the cost of emission controls. One approach being considered in the United States would be adoption of technical regulations limiting the carbon intensity of basic products, such as cement, aluminum, steel, etc., offered for sale in the US market (carbon intensity would be defined as the $\mathrm{CO}_{2}$ equivalent emissions per ton of product). Domestic and imported products that exceed the regulation limit could not be sold in US commerce, except pursuant to exceptions that would be available on a national treatment basis. Technical regulations would be based on the quantity of carbon equivalent gases emitted in the production of a unit of product, such as a ton of steel. The regulations would set a numerical limit on carbon intensity; would set discrete limits for different products and types of manufacture; would require auditable facility measurement but could allow compliance on an average company-wide basis; and would be tightened over time to encourage new technologies. However, there would be no requirement for the adoption of specific technologies.

The article will analyze the validity of such regulations under the World Trade Organization (WTO) Agreement on Technical Barriers to Trade (TBT Agreement). ${ }^{1}$ The preamble to the TBT Agreement recognizes that "no country should be prevented from taking measures necessary ... for the protection of human, animal or plant life or health, [or] of the environment ... at the levels it considers appropriate". In addition, TBT Agreement Article 2.2 includes "protection of human health or safety ... or the environment" as legitimate objectives of technical regulations. The article will examine whether a maximum carbon emission limit would be a "[t]echnical regulation" as defined by the TBT Agreement Annex 1.1, taking into account the WTO Appellate Body statement that characteristics subject to regulation are not limited to "qualities intrinsic to the product itself". Consideration will also be given to the TBT Agreement requirement that technical regulations should not be applied so as to create unnecessary obstacles to trade. Finally, there will be an evaluation of the application of Article III of the General Agreement on Tariffs and Trade (GATT) ${ }^{2}$ to measures that qualify as technical regulations.

\section{Introduction}

In 2007, both houses of the US Congress began serious consideration of proposals to regulate carbon emissions in response to escalating concerns about global warming. One approach, which has been

* Charles Owen Verrill, Jr., Partner, Wiley Rein, Washington, D.C., and Senior Lecturing Fellow, Duke University School of Law, Durham, North Carolina.

1 Agreement on Technical Barriers to Trade (TBT), 18 I.L.M. 1979, p. $1079 \mathrm{ff}$. incorporated in legislation reported out of the Senate Committee on Environment and Public Works, would require the US government to adopt a "cap and trade" system that would apply to domestic carbon emitters and, ultimately, to imports. ${ }^{3}$ In broad outline, such a cap and trade system

2 General Agreement on Tariffs and Trade 1994, contained in the Marrakesh Agreement Establishing the World Trade Organization, Annex 1A, 33 I.L.M. 1994, p. 1153 ff.

3 110th Congress, American Climate Security Act, S. 2191 (2007), www.govtrack.us/congress/bill.xpd?bill=s110-2191. 
would establish aggregate limits ("caps") on emissions of greenhouse gases (carbon dioxide, methane, nitrous oxide and fluorinated gases) from all direct sources of emissions in the US economy, including power generation, manufacturing, and possibly transportation. The "cap" would be divided into allowances, which would be allocated to operating entities either by auction or based on traditional emission levels. Domestic entities would have to submit allowances to a federal authority equal to their annual greenhouse gas emissions. Entities that emit gases below their limit could sell or trade excess allowances to other entities that do not meet their emission limits. ${ }^{4}$ Recognizing that US industry would be at a competitive disadvantage if foreign manufacturers of products for the domestic market in the United States are not subject to comparable emission limits, proposals now under consideration in Congress require that importers would also have to provide allowances covering the greenhouse gases emitted in the country of origin, or otherwise demonstrate compliance with emission limits comparable to those applicable to domestic producers. ${ }^{5}$

Concerned about the cost of mandatory participation in a cap and trade system, and the uncertain global reach of pending legislative proposals, certain US industries have proposed as an alternative the adoption of federally mandated maximum carbon intensities for certain basic products (e.g., steel, paper, aluminum, plastics, cement, and so on). ${ }^{6}$ Under this system, manufacturers of basic products would be exempt from allowance requirements. The proposed limitations would be based on the quantity of carbon equivalent gases (the "carbon intensity") emitted in the production of a unit of product, such as a ton of steel or cement. The measure would set discrete numerical limits on carbon intensity for different products and manufacturing processes that would be tightened over time to limit emissions and encourage new technologies. Products with carbon intensities that exceed the maximum would not be permitted for sale in US commerce, regardless of where they are produced, except pursuant to exceptions that would be available equally for domestic and imported products.

A carbon intensity technical regulation applied alike to domestic and imported products would be justified as necessary to protect both human life and the environment from the risks associated with excessive carbon emissions. Emissions from US and foreign sources contribute to global greenhouse gas concentrations and migrate through the atmosphere of the United States as well as other countries. The proposed measure would require domestic producers to reduce greenhouse gas emissions, and foreign producers would have to do so as well in order to have access to the US market. The application of the carbon intensity limits to imports, as well as domestic production, would be necessary to avoid giving imports produced without carbon intensity limitations an unfair competitive advantage in the US market. Whether that would be consistent with the international obligations of the US is the issue considered in this Article.

The WTO obligations of the United States, including GATT 1994 Articles III and $\mathrm{XI}^{7}$ are generally applicable to restrictions on imports. However, this paper argues that a measure imposing limits on carbon intensity that is adopted consistent with the TBT Agreement would not be subject to either GATT 1994 Articles III or XI. Otherwise, a measure that is consistent with the TBT Agreement could be invalidated if it is found to be inconsistent with GATT 1994. This anomalous result is precluded by the WTO Agreement, which provides that in the case of a conflict with GATT 1994, the TBT Agreement should prevail.

A measure is consistent with the TBT Agreement if it is a technical regulation that lays down mandatory product characteristics, is non-discriminatory, is adopted consistent with the specified procedural requirements, and is not unnecessarily traderestrictive. Application of the TBT Agreement to a measure similar to that proposed to limit greenhouse gas emissions from basic manufacturing has never been authoritatively considered by a WTO panel or the Appellate Body. However, based on the Preamble and terms of the TBT Agreement, and

4 See Committee on Energy and Commerce, Subcommittee on Energy and Air Quality, Climate Change Legislation Design White Paper: Competitiveness Concerns/Engaging Developing Countries, January 31, 2008, p. 8-10, http://energycommerce. house.gov/Climate_Change/White_Paper.Competitiveness.013108.pdf.

5 Ibid. See also S.2191, supra, note 4, Title VII, Global Efforts to Reduce Greenhouse Gas Emissions, sections 6001-6007.

6 See, generally, Climate Change White Paper, supra, note 4, pp.10-11.

7 GATT Article III requires national treatment on internal taxation and regulation; Article II requires general elimination of quantitive restrictions. 
statements in Appellate Body decisions concerning the meaning of technical regulations as that term is used in the TBT Agreement, there are persuasive arguments that a measure establishing maximum carbon intensities would be found to be a technical regulation that would comply with the Agreement if the salient principles and procedures are scrupulously followed.

\section{The TBT Agreement Places Special Emphasis on Protection of the Environment}

Protection of the environment and human health are specifically recognized as legitimate bases for regulation by WTO members pursuant to the TBT Agreement. The Preamble to the TBT Agreement "recognizes" that "no country should be prevented from taking measures necessary ... for the protection of human, animal or plant life or health" or "of the environment ... at levels it considers appropriate." The exercise of this authority should, however, not result in measures that are "applied in a manner which would constitute a means of arbitrary or unjustifiable discrimination between countries where the same conditions prevail or a disguised restriction on international trade." This admonition is echoed in TBT Agreement Article 2.2, which states that technical regulations should "not be more trade restrictive than necessary to fulfill a legitimate objective." Then, Article 2.2 lists "protection of human health or safety ... or the environment" as legitimate objectives of technical regulations. The Preamble's emphasis on the right of countries to take measures necessary for the protection of the environment and human health should inform the interpretation of the TBT Agreement provisions. ${ }^{8}$

8 According to the Vienna Convention on the Law of Treaties (VCLT), 8 I.L.M. 1969, p. 679 ff., Article 31, Preambles are part of the context which must be evaluated in treaty interpretation.

9 TBT Agreement, Annex 1.1.

10 European Communities - Measures Affecting Asbestos and Asbestos-Containing Products, Report of the Appellate Body, WTO Doc. WT/DS/AB/R, paras. $66 \mathrm{f}$.

\section{A Measure Regulating Carbon Inten- sity Would be a Technical Regulation as defined by the TBT Agreement}

A "technical regulation" is defined by Annex 1.1 of the TBT Agreement as a "[d] ocument which lays down product characteristics or their related processes and production methods, including the applicable administrative provisions, with which compliance is mandatory"..$^{9}$ Thus, the first question is whether a carbon intensity regulation would lay down "product characteristics" given that the regulation would relate to carbon emitted during the manufacture of steel and other basic products. Since the emitted carbon would not be in the product at the time of sale (or, in the case of foreign products, at the time of sale after importation), each product would have to be identified by the carbon emissions during its production at the producing facility either on a product-by-product or process-by process-basis. The issue then is whether that identifier is a characteristic of the product as that term is used in the TBT Agreement.

The Appellate Body in EC - Asbestos ${ }^{10}$ considered whether a ban by France on asbestos, and products containing asbestos, violated the TBT Agreement as a technical regulation that was more restrictive of trade than necessary. In considering whether the French regulation was a technical regulation, the Appellate Body first addressed the issue whether the regulation prescribed a "characteristic". The Appellate Body stated that the word "characteristic" as used in the TBT Agreement has a number of "synonyms that are helpful in understanding the ordinary meaning of that word". The characteristics of a product include "any objectively definable 'features,' 'qualities, ' attributes,' or other 'distinguishing mark' of a product." This sentence is followed by a statement that such "characteristics' might relate, inter alia, to a product's composition, size, shape, colour, texture, hardness, tensile strength, flammability, conductivity, density or viscosity." And, the Appellate Body further stated that product characteristics "include, not only features and qualities intrinsic to the product itself, but also related 'characteristics,' such as the means of identification". In support of this conclusion, the Appellate Body referred to Annex 1.1 of the TBT Agreement, which gives as examples of product characteristics "terminology, symbols, packaging, marking or labelling 
requirements." According to the Appellate Body, these "examples indicate that 'product characteristics' include, not only features and qualities intrinsic to the product itself, but also related 'characteristics,' such as the means of identification, the presentation and the appearance of a product." ${ }^{11}$

The conclusion that the "characteristics" subject to the TBT Agreement do not need to be intrinsic to the product itself was also emphasized in EC Sardines. ${ }^{12}$ That decision involved the WTO consistency of a measure by the European Union that permitted only fish of the species Sardinia pilchardus to be labeled and marketed as preserved sardines. Peru, which is a major exporter of sardines (but not of the species Sardinia pilchardus), challenged the regulation as an impermissible technical regulation, arguing that the international standard, the Codex Alimentarius, provides that fish from other species can be sold as sardines, so long as either the species or the geographical origin of the fish is specified. The Appellate Body first noted that "whether a measure is a 'technical regulation' is a threshold issue because the outcome of this issue determines whether the TBT Agreement is applicable." Citing with approval the decision in EC Asbestos, the Appellate Body concluded that features such as "means of identification" would be a characteristic under the TBT Agreement because "a name clearly identifies a product." Thus, an EC regulation relating to the marketing of "preserved sardines which only included fish of the species Sardinia pilchardus" laid down a characteristic that was covered by the TBT Agreement. ${ }^{13}$

These precedents, while not directly on point, do evidence a disposition to broadly define the term "characteristics" as that term is used in the TBT Agreement. And, for purposes of this analysis, the important point that has been made by the Appellate Body in construing this term is that "characteristics" are not limited to "qualities intrinsic to the product itself". Thus it would not be dispositive that the carbon intensity of a basic product is measured during the production process and cannot be derived from a physical analysis of the product itself. What should be dispositive, instead, is whether the carbon intensity of a basic product like steel or cement can be "objectively" defined. Assuming that to be the case, it would be reasonable to anticipate that a carbon intensity regulation would be viewed as a means of identification that qualifies as a "characteristic" as that term is defined in the TBT Agreement.

According to industry sources, the carbon intensity of basic products can be "objectively" established. For example, the International Iron and Steel Institute has stated that the "steel industry has collected, and will maintain, the most comprehensive set of environmental data for its products." This data includes "a detailed assessment of $\mathrm{CO}_{2}$ emissions on a process-by-process or product basis." ${ }^{14}$ In the case of steel, that record is intrinsic to each ton and can be used as a means of identification. It is the author's understanding that other basic products have similar objectively derived data on carbon emissions. It would, therefore, be practical to require a label or mark specifying carbon intensity.

In sum, there is a strong case to be made that a measure regulating carbon intensity would be a deemed a "technical regulation" as defined in the TBT Agreement and its Annex 1, even though the emitted carbon does not reside in the basic product at the time of sale or importation for sale. The Appellate Body has indicated that it does not matter whether the characteristic is intrinsic to the product itself as long as there is an objectively defined means of identification. The amount of carbon emitted during product manufacture can be measured and is, therefore, a distinguishing feature of each individual unit.

A supple interpretation of "characteristic" would be consistent with the Preamble to the TBT Agreement, which "recognizes" that "no country should be prevented from taking measures necessary ... for the protection of human, animal or plant life or health, of the environment ... at levels it considers appropriate". Since international law on the interpretation of treaties set out in the Vienna Convention provides for the consideration of preambles as part of the "context" for treaty interpretation, this statement should inform the meaning

\footnotetext{
11 lbid., para. 67.

12 European Communities - Trade Description of Sardines, Report of the Appellate Board, WTO Doc. WT/DS 231/AB/R, para. 6 ("product characteristics may be intrinsic, or they may be related to the product").

13 Ibid., para. 5.

14 International Iron and Steel Institute, A Policy to Reduce Steelrelated Greenhouse Gas Emissions, http://www.jernkontoret.se/ JernKontoret/pressmedde/anden/2007/climatechangepolicyfinal. pdf, p. 4.
} 
given to "characteristics". In addition, Article 2.1 includes "protection of human health or safety ... or the environment" as legitimate objectives of technical regulations. Since technical regulations adopted with the objective of limiting carbon intensity would be designed to protect the environment, and would be a means of identification of the carbon intensity of a specific unit of products affected by the regulations, a conclusion that such regulations lay down product "characteristics" would be warranted, even though those characteristics are defined during production and are not intrinsic to the product itself.

In this connection, it is important to note that the TBT Agreement specifically refers to process production method (PPM) measures in the definition of a technical regulation. Specifically, Annex 1.1 defines a technical regulation as a measure that applies to "product characteristics or their related processes and production methods". PPMs are therefore included within the meaning of technical regulations if they are related to product characteristics. According to an interpretive note by the WTO Secretariat issued shortly after the adoption of the Uruguay Round Agreements, ${ }^{15}$ the word "their" was inserted "to ensure that the Agreement will only address a narrow selection of processes and production methods." 16

The "narrow selection" of PPMs that are permitted by the TBT Agreement has to be informed by the definition of "characteristics" that has been adopted by the Appellate Body. As noted above, the term "characteristics" is not limited to features intrinsic to the product itself. And, since there is a good argument that carbon intensity limitations are definable as "characteristics," there is also a similarly good argument that such limitations would be deemed "related process and production methods" that are among the "narrow selection" of PPMs permitted by the express language of the TBT Agreement. ${ }^{17}$

15 WTO Note Prepared by the Secretariat on its own Responsibility, WTO Doc. WT/CTE/W/10.

16 Ibid., para. 147.

17 "This provision [the definition of technical regulation] could be interpreted as covering non-product related PPMs, making technical regulations on non-product related $P \mathrm{PM}^{\prime} \mathrm{s}$ permissible provided they meet the other requirements of the TBT Agreement", Green, "Climate Change, Regulatory Policy and the WTO", Journal of International Economic Law 2005, p.160.

$18 \mathrm{EC}-$ Asbestos, supra, note 11, para. 68.
Finally, the definition of technical regulation in TBT Agreement Annex 1.1 also states that compliance with the product characteristics laid down must be "mandatory", in that the regulation "has the effect of prescribing or imposing one or more characteristics." As envisioned, the proposed technical regulation would provide that products would have to have a carbon intensity below a benchmark (with differential levels based on manufacturing process, etc.), in order to be sold in US commerce. This seems to clearly meet the mandatory requirement. Moreover, there would seem to be no bar to laying down certain exceptions. In EC - Asbestos, the Appellate Body indicated that "applicable administrative provisions" which objectively provide for exceptions remain mandatory and within the definition of technical regulation. ${ }^{18}$

\section{The Like Product Requirement Would not Preclude Application of CIM to Domestic and Imported Products}

The carbon intensity of a basic product would be derived from the production process. As a practical matter, it would appear necessary to adopt different intensity limits for discrete processes even though they result in like products. For example, the regulations could include a carbon intensity limitation for steel produced in the electric furnace (EAF) method, which relies largely on scrap iron as the "feed" or raw material input, and has a low level of emissions. There is a different environmental impact when similar steel is produced in the basic oxygen furnace (BOF) method, which uses iron ore (and some scrap) as the raw material. In this process, the carbon emitted during production is significantly greater than occurs in electric furnace production, even though the production method does not affect the physical characteristics of the finished steel. For example, steel beams produced in an electric furnace mill are, for the most part, physically identical to beams produced in the BOF mill. Notwithstanding this similarity in the end products, it would seem logical and appropriate to adopt discrete carbon intensity limits for steel produced by the two methods.

Article 2.1 requires Members to ensure that technical regulations do not discriminate between imported and domestic like products, or among imports from different WTOMember States. There 
is an issue here because a product produced in one process common to the United States might have a different intensity than the same product produced in another process domestically or in a foreign country. For example, domestic steel beams produced in the electric furnace process would have a lower carbon intensity than foreign steel beams produced in the basic oxygen furnace method, yet all such beams would have similar characteristics as far as the consumer is concerned. As a result, an imported BOF beam would not be able to meet the more stringent intensity standard that would apply to either an imported or domestic EAF beam. ${ }^{19}$ Yet, while all these beams would appear to be "like" products by any commercial standard, the potential for discriminatory treatment of BOF beams does not necessarily indicate that carbon intensity regulations would be prohibited by Article 2.1.

The definition of like products is a flexible concept in WTO law. For example, in Japan - Alcoholic Beverages, the Appellate Body observed that the "accordion of 'likeness' stretches and squeezes in different places as different provisions of the WTO Agreement are applied. ${ }^{20}$ Despite this flexibility, it is difficult to imagine a finding that EAF and BOF steel beams are not "like" under the usual criteria which consider (i) the physical properties, (ii) end uses, (iii) consumer tastes and perceptions, and (iv) tariff classifications. ${ }^{21}$ There are no differences between EAF and BOF beams under these criteria and they would clearly, therefore, be considered like for purposes of Article 2.1 of the TBT Agreement. But, the analysis must not stop there.

In the recent Appellate Body decision involving Dominican Republic - Cigarettes, the Appellate Body looked beyond mere likeness considerations to hold that a detrimental effect on a like imported product is acceptable as long as it is "explained by factors or circumstances unrelated to the foreign origin of the product." ${ }^{22}$ This interpretation was based on a reading of Article II.4 of GATT 1994, which has language relating to national origin that is very similar to TBT Agreement Article 2.1. This reasoning would justify different regulations for electric furnace and BOF steel, even though the end products of these processes are "like", because the differential treatment would not be based on national or foreign origin, but rather on the process.

In fact, the "differential treatment" would facilitate trade, since a carbon intensity regulation common to both EAF and BOF beams would potential- ly be a much greater burden on imports. For example, an intensity regulation based solely on EAF best practices would be an impossible hurdle for an imported BOF product. Therefore, recognition of the process differential in the establishment of intensity limits would avoid creating "a disguised restriction on international trade" in like products. Moreover, it would be consistent with the admonition of TBT Agreement Article 2.2 that technical regulations "not be more trade restrictive than necessary to fulfill a legitimate objective."

\section{Procedures Applicable to the Adoption of Technical Regulations}

Article 2 of the TBT Agreement specifies a number of requirements that central government bodies must satisfy in adopting technical regulations. These requirements provide a roadmap that is designed to ensure that technical regulations are not unduly trade restrictive. At this time, given the lack of precise indications of how technical regulations would be formulated, only general comment can be provided on the procedures that are necessary to ensure TBT Agreement compliant regulations.

\section{Nondiscrimination}

Article 2.1 requires Members to ensure that technical regulations do not discriminate between imported and domestic like products, or among imports from different WTO Member States. This obligation, which is parallel to the national treatment obligation of GATT Article III.4, is dealt with in section 4 , supra.

19 For example, assume that the US intensity limit for beams is based on the predominant EAF method. Foreign beams which are often produced in the BOF process could not meet the limit even though the products are the same metallurgically and competitive in price and customer perception. Therefore, there would be a clear discrimination against the foreign $\mathrm{BOF}$ beams that are like domestic EAF beams if the US based the technical regulation on the emissions from EAF production.

20 Japan - Taxes on Alcoholic Beverages, Report of the Appellate Body, WTO-Docs. WT/DS8/AB/R, WT/DS10/AB/R, WT/DS11/AB/R, p. 22.

21 See, EC - Asbestos, supra, note 10, at paras. 88-91.

22 Dominican Republic - Measures Affecting the Importation and Internal Sale of Cigarettes, Report of the Appellate Body, WTO Doc. WT/DS302/AB/R, para. 96. 


\section{No Unnecessary Obstacle to Trade}

Article 2.2 of the TBT Agreement states that technical regulations must not be "prepared, adopted or applied with a view to or with the effect of creating unnecessary obstacles to international trade." Moreover, technical regulations must not be more trade-restrictive than necessary to fulfill a legitimate objective (including, but not limited to, protection of human health or safety, animal or plant life or health, or the environment), taking account of the risks non-fulfillment would create. In assessing such risks, relevant elements to consider are, inter alia, available scientific and technical information, related processing technology, or intended end-uses of products.

There is no doubt that the objective of carbon intensity regulations would be considered legitimate, given the statement of objectives in TBT Agreement Article 2.2 ("[s]uch legitimate objectives are ... protection of human health or safety ... or the environment") and the declaration in the Preamble that Members have the right to take measures to protect the environment and human health. Available scientific and technical information all point to emission of greenhouse gases as a significant threat to the environment and human health.

Assuming the objective is legitimate, the regulation must also meet the "no more trade restrictive than necessary" requirement of Article 2.2, taking into account the risks of nonfulfillment. Carbon intensity regulations would, of course, be trade restrictive, as they would entirely bar sale in US commerce of imported products that did not meet the standards or applicable exceptions. Thus, the question to be resolved is whether such measures are more trade restrictive than necessary.

While this specific provision has never been the subject of a WTO panel or Appellate Body decision, there are numerous decisions based on GATT 1994 Article XX (b), which provides an exception for measures "necessary to protect human, animal or

23 United States - Import Prohibition of Certain Shrimp and Shrimp Products, Report of the Appellate Body, WTO Doc.

WT/DS58/AB/R, para. 30. Although the Appellate Body upheld this principle, it found the specific measures at issue to violate the GATT, principally because they were applied in a discriminatory fashion.

24 Korea - Measures Affecting Imports of Fresh, Chilled or Frozen Beef, Report of the Appellate Body, WTO Doc. WT/DS161/AB/R, para. 159.

25 EC-Asbestos, supra, note 10, para. 172. plant life or health" so long as they are not a disguised restriction on international trade. In construing the Chapeau of Article XX, the Appellate Body appears to have upheld the principle that the US could unilaterally require other countries to adopt certain policies (in the case under consideration, the adoption of measures to ensure turtle friendly shrimp harvesting), where those policies were comparable in effectiveness. ${ }^{23}$ This reading would suggest by analogy that carbon intensity regulations would be judged by whether they would require foreign governments to adopt regulations or policies with comparable effectiveness to the US measure.

It must be remembered, though, that the TBT Agreement does not have an analogue provision to GATT 1994, Article XX. Moreover, in evaluating trade restrictiveness under TBT Agreement Article 2.2, Members are entitled to take into account the risk of non-fulfillment of the objectives of a technical regulation, which together with the TBT Agreement's Preamble emphasis on the right of Members to take measures to protect the environment or human health, indicate that a more relaxed application of the trade restrictive test would be appropriate in evaluating a carbon intensity regulation under the TBT Agreement.

It does seem likely that the Appellate Body would want an analysis of whether there are reasonably available measures that would achieve the same objective with less of an impact on trade. In Korea - Beef, ${ }^{24}$ the Appellate Body noted that to determine if an alternative measure is reasonably available, factors to be taken into account are difficulty of implementation and the extent to which any alternative measure would contribute to the objective pursued. In addition, the Appellate Body in EC - Asbestos noted that the "more vital or important [the] interests or values pursued", the "easier it would be to accept as necessary measures designed to achieve those ends." ${ }^{25}$ There is no question concerning the urgency of the need to take measures to deal with global warming, which should increase the likelihood that carbon intensity regulations would be acceptable.

The alternatives to a carbon intensity technical regulation would include a carbon intensity tax, which is politically difficult and would raise problems under GATT Article III.2, or a cap-and-trade system, which would seem to pose more questions under the GATT than a regulation that is consistent 
with the TBT Agreement. Most commentators recognize that a cap-and-trade regime applied to imports would likely require an exception under GATT Article XX (b) and its chapeau. In these circumstances, the "necessary" test under the TBT Agreement would likely survive Appellate Body scrutiny.

We recognize that in decisions under the SPS Agreement, WTO Panels and the Appellate Body have not exhibited a high degree of deference to the determinations of national regulators that measures covered by the Agreement have the requisite scientific basis. Unlike the SPS Agreement, which requires that measures be "based on scientific principles and not maintained without sound sufficient scientific evidence," the TBT Agreement requires only "consideration" of scientific evidence. Thus, it is likely to be easier to justify a measure with an uncertain scientific basis under the TBT Agreement.

\section{Based on International Standards}

Article 2.4 requires that existing international standards be utilized, unless they would be ineffective for the purposes and objectives pursued. There are no known carbon intensity limitations that could be used as a model. There is the Kyoto Protocol, which sets targets for overall greenhouse gas emissions, but it expires in 2012 and is not product or process specific. Indeed, there is no international consensus on the best approach to controlling greenhouse gases. While Article 2.5 provides that regulations based on international standards enjoy a rebuttable presumption of compliance with the requirements of Article 2.2, the lack of such standards does not preclude adoption of regulations that otherwise comply with the TBT Agreement.

\section{Equivalent Standards}

Members shall give positive consideration to accepting as equivalent technical regulations of other Members, even if these regulations differ from their own, provided they are satisfied that these regulations adequately fulfill the objectives of their own regulations. Here again, there are no alternate regulations that could be used as the basis for a US regulation.

\section{Performance-based}

Wherever appropriate, Members shall specify technical regulations based on product requirements in terms of performance. As envisioned, the intensity carbon regulation would specify a benchmark, leaving it to the regulated industries to determine how best to achieve compliance.

\section{Procedural Requirements}

In addition to the substantive requirements described above, the TBT Agreement imposes a number of procedural requirements relating to the promulgation of technical regulations that are subject to the Agreement. None of these requirements appear to be problematic. They are described below, however, to indicate the steps that must be followed in order to promulgate the carbon intensity regulation in a manner consistent with the TBT Agreement.

A Member preparing, adopting or applying a technical regulation which may have a significant effect on trade of other Members is required by Article 2.9, upon the request of another Member, to explain the justification for that technical regulation in terms of the provisions of the TBT Agreement.

Except in urgent situations, for technical regulations that are not based on a relevant international standard, Article 2.9 requires Members to publish a notice in a publication at an early appropriate stage, in such a manner as to enable interested parties in other Members to become acquainted with the proposal. It is also required that other Members be notified, through the Secretariat, of the products to be covered by the proposed technical regulation, together with a brief indication of its objective and rationale. Such notifications shall take place at an early appropriate stage, when amendments can still be introduced and comments taken into account. Upon request, other Members must be provided with particulars or copies of the proposed technical regulation together with identification of the parts which in substance deviate from relevant international standards. Finally, it is required to allow reasonable time for other Members to make comments in writing, discuss these comments upon request, and take these written comments and the results of these discussions into account. 
Except in those urgent circumstances, Article 2.12 requires Members to allow a reasonable interval between the publication of technical regulations and their entry into force in order to allow time for producers in exporting Members, and particularly in developing country Members, to adapt their products or methods of production to the requirements of the importing Member.

\section{Differential Treatment for Developing Countries}

Like many of the other WTO Agreements, the TBT Agreement provides for special and differential treatment of developing and least developed countries. Specifically, Article 12.3 of the TBT Agreement provides that "Members shall, in the preparation and application of technical regulations, standards and conformity assessment procedures, take account of the special development, financial and trade needs of developing country Members, with a view to ensuring that such technical regulations, standards and conformity assessment procedures do not create unnecessary obstacles to exports from developing country Members."

Because compliance with carbon intensity standards may pose particular difficulties for at least some developing country Members of the WTO, this provision may potentially come into play in any challenge. It is not clear what, precisely, this provision requires, as neither it, nor any other provision of the WTO Agreements relating to special treatment of developing countries, has been the subject of WTO dispute settlement decisions. In any event, the application of Article 12.3 would not appear to require differential treatment where development of industrial sectors is not restricted

26 Ibid., para. 152 (emphasis omitted).

27 European Communities - Regime for the Importation, Sale and Distribution of Bananas, Report of the Appellate Body, WTO Doc. WT/DS27/AB/R.

28 See the discussion of this issue in Hudec, "The Product-Process Doctrine in GATT WTO Jurisprudence ${ }^{\prime \prime}$, in Bronckers/Quick (eds.), New Directions in International Economic Law: Essays in Honour of John H. Jackson, The Hague 2000, p.18.

29 See, EC - Asbestos, supra. In that connection, see also Marceau/Trachtman, "The Technical Barriers to Trade Agreement, the Sanitary and Phytosanitary Measures Agreement, and the General Agreement on Tariffs and Trade A Map of the World Trade Organization Law of Domestic Regulation of Goods", Journal of World Trade 2002, at 811 . The authors suggest a narrow reading of "like" in the TBT Agreement given its purposes. by lack of capital or limited access to the latest technologies.

\section{A Measure Justified Under the TBT Agreement Would Not Be Required to Meet GATT 1994}

Assuming that a carbon intensity regulation would be a characteristic appropriate for regulation under the TBT Agreement, it is next necessary to evaluate whether other GATT-1994 obligations, particularly Article III, would also be applicable. In EC Asbestos, the Appellate Body stated that the TBT Agreement "imposes obligations on Members that seem to be different from, and additional to, the obligations imposed on Members under the GATT 1994." ${ }^{26}$ Moreover, in EC - Bananas, the Appellate Body concluded that a measure could violate both the Services Agreement and GATT 1994. ${ }^{27}$

As an initial matter, it is clear that carbon intensity regulations would be non-product related PPMs. There is authority that such measures are not consistent with Article III of GATT-1994 to the extent that they apply different requirements to like products. ${ }^{28}$ This so-called product-process method doctrine, which derives from an interpretation of the ad-note to Article III, is said to prohibit regulations based on the production process that have no effect on the intrinsic characteristics of the product. Under this definition, it seems clear that regulations limiting the level of carbon emitted in the production process would be considered a PPM, since the physical properties of the finished product are not affected by the emissions involved. Moreover, in the case of steel, EAF products are like BOF products under the standard tests. ${ }^{29}$

Given the probability that different carbon intensity regulations would be necessary for certain basic products that are nevertheless like, such regulations would appear to be inconsistent with GATT 1994, Article III, as interpreted by the decisions that set forth the PPM doctrine. Therefore, it would be necessary, assuming that GATT 1994 is applicable, to resort to Article $\mathrm{XX}$, which provides general exceptions to the GATT 1994 obligations for otherwise inconsistent measures that not unjustifiably discriminatory or a disguised restriction on international trade. There is speculation that the Appellate Body decision in the US - Shrimp Products dispute, which dealt with an interpretation of Article 
$\mathrm{XX}$, seems to implicitly endorse a unilaterally applied PPM that differentiated shrimps based on the method of capture. ${ }^{30}$ However, analysis of the extent to which a carbon intensity regulation would be deemed compliant with the chapeau of Article $\mathrm{XX}$ would not be necessary if the regulation is not required to conform to GATT 1994 on the ground that the TBT Agreement takes precedence.

A strong case can be made that compliance with the TBT Agreement should be the exclusive WTO obligation that would apply to a compliant technical regulation. In the first place, the basic principles concerning national treatment set out in GATT 1994 Article III are also embodied in Article 2.1 of the TBT Agreement. This suggests that the drafters intended that the Article 2.1 requirement be the only national treatment obligation. Moreover, TBT Agreement Article 2.2 requires members to ensure that technical regulations "are not prepared, adopted or applied ... with the effect of creating unnecessary obstacles to international trade." Nor should such measures be more "trade-restrictive than necessary to fulfill a legitimate objective". Given these constraints that are internal to the TBT Agreement, it would be redundant to also require compliance of a technical regulation with GATT 1994.

This analysis is buttressed by an interpretative note to the Agreement establishing the World Trade Organization," which provides that "[I]n the event of conflict between a provision of the General Agreement of Tariffs and Trade 1994 and a provision of another agreement [e.g., the TBT Agreement] ... the provision of the other agreement shall prevail to the extent of the conflict." ${ }^{32}$

The TBT Agreement is in conflict with the GATT on a key point. As we have noted, and the EC Asbestos and EC - Sardines cases confirm, the TBT Agreement applies to characteristics that are not intrinsic to the product, an interpretation that permits technical regulations that are process based. Thus, assuming the validity of the PPM doctrine as applied to GATT 1994 Article III, application of this doctrine to a technical regulation that meets all other TBT Agreement requirements would result in clear conflict with the TBT Agreement. Therefore, a regulation under the TBT Agreement that meets its requirements would prevail over a contrary application of GATT 1994 Article III.

Finally, it would appear incumbent on the Appellate Body to interpret the relevant agreements to give maximum effect to both the TBT
Agreement and the GATT. This principle would be obviated if a regulation sanctioned under the TBT Agreement were to be invalidated because of an aggressive interpretation of Article III under the guise of the PPM doctrine. This would conflict with the "principles of effective interpretation pursuant to which all provisions of a treaty ... must be given meaning, using the ordinary meaning of words." ${ }^{33}$ Moreover, "an interpreter is not free to adopt a reading that would result in reducing whole clauses or paragraphs of a treaty to redundancy or inutility." ${ }^{34}$ As noted above, "a narrow selection" of process-based regulations are permitted under the TBT Agreement, even if there is a question about their appropriateness under GATT Article III. As such, those regulations, assuming they are fully compliant with the TBT Agreement, should not be subject to redundant requirements of GATT 1994 .

\section{Conclusion}

A very compelling case can be made that the regulation of greenhouse gas emissions by technical regulations would be consistent with the TBT Agreement, assuming the procedural requirements for the adoption of such regulations were scrupulously observed. While such regulations would be restrictive of trade, the TBT Agreement specifically

\footnotetext{
30 See CUTS Briefing Paper No. 7/2000 at 4, Process and Production Methods (PPMs) - Implications for Developing Countries; RO53 ISEAL - CIEL Legal Opinion, July 2006, at 4, 6. (“The Appellate Body appeared to suggest that it was not the extraterritorial application of US environmental standards that violated WTO rules in this case, but the arbitrary manner in which the US law was applied.")
}

31 Marrakesh Agreement Establishing the World Trade Organization, 33 I.L.M. (1994), p. $1144 \mathrm{ff}$.

32 Ibid., Annex 1A, General Interpretative Note, http://www.wto.org/english/docs_e/legal_e/final_e.htm, which states that in "the event of a conflict between a provision of [the General Agreement on Tariffs and Trade 1994 and a provision of another agreement in Annex 1A to the Agreement Establishing the WTO], the provision of [the other] agreement shall prevail to the extent of the conflict."

33 Indonesia - Certain Measures Affecting the Automobile Industry, Report of the Panel, WTO Docs. WT/DS54/R, WT/DS55/R, WT/DS59/R, WT/DS64/R, para. 14.28.

34 United States - Standards for Reformulated and Conventional Gasoline, Report of the Appellate Body, WTO Doc.

WT/DS2/AB/R, p. 21; see generally Pauwelyn, "The Role of Public International Law in the WTO: How Far Can We Co?", American Journal of International Law 2001, p. $535 \mathrm{ff}$. 
defines protection of the environment and human health as legitimate objectives of technical measures, and allows consideration of the risk of nonfulfillment of such objectives in their adoption.
Given the magnitude of the world-wide effects of global warming, and their likely effectiveness, carbon intensity regulations would not seem to be an unnecessary restraint on trade. 